\title{
NEWS REPORTS
}

\section{CGMW Reviews its Map Program}

During its recent Plenary Assembly in Paris, February 1987, the Commission for the Geological Map of the World (CGMW), an IUGS affiliate, reviewed its existing activities and launched several new projects. Appointments confirmed were J.M. Aaron (U.S.A. and Chairman of IUGS Advisory Board on Publications) Vice President for North and Central America, V.E. Khain (U.S.S.R.) President, Yu. Leonov (U.S.S.R.) Secretary-General of the Subcommission for Tectonic Maps, and G.O. Kesse (Ghana) Vice President for Africa. The Bureau also moved to establish links with the new IUGS-sponsored Circum-Atlantic Project.

Substantial progress was noted toward the preparation of a world geological wall map, an international plate tectonics map of the world $(1: 10,000,000)$, the third edition of the Geological Map of Africa (six sheets to be completed before the 28th International Geological Congress in 1989), and new geological maps at $1: 5,000,000$ of South America (in preparation), South and East Asia (3rd edition now in draft form), Europe (in preparation), and the Middle East (printed recently by the Geological Survey of Iran). New tectonic maps at 1:5,000,000 are being prepared for Europe, Africa and Asia, and metallogenic maps for South and East Asia (published recently), Europe (an explanatory memoir is now complete) and Africa (first sheet scheduled for publication in 1987). A bibliography of metallogenic maps is now being prepared for CGMW by the U.S. Geological Survey, and an experimental atlas of world mineral deposits is also under consideration. A metamorphic map $(1: 10,000,000)$ has recently been published for South and East Asia (together with explanatory notes), and maps for South America are also now being prepared.

The CGMW Bureau in Paris set up a new Subcommission for Hydogeological Maps under the Presidency of W. Struckmeier (F.R.G.), who is also the Chairman of the IAH Commission for Hydrogeological Maps. The subcommission will monitor progress of the new hydrogeological map of South America, to be published by Brazil, and the new six-sheet hydrogeological map for Africa, being prepared by the Association Africain de Cartographie. Finally, the Commission noted the recent publication of the seismotectonic map of Iran-Afghanistan-Pakistan $(1: 5,000,000$, together with accompanying explanatory notes) as a step towards a seismotectonic map for the entire Middle East.

\section{Site Set for German Super-Deep Hole}

The location of the first super-deep research borehole to be drilled under the Continental Deep Drilling Program of the Federal Republic of Germany has been set in the Oberpfälz Forest of Bavaria, on the northwestern corner of the Bohemian Massif. A pilot hole is now in progress, with the main drilling scheduled to start in 1989.

The decision to select the Oberpfälz as the target area for the first German super-deep borehole was strongly influenced by the possible risks involved in drilling. Of particular significance were the results of the geothermal investigations, which showed for the Schwarzwald basement, the other site considered, a considerably higher near-surface heat flow and higher temperature gradients than in the Oberpfälz. At a depth of $7-8 \mathrm{~km}$ here a temperature of $300^{\circ} \mathrm{C}$ might be reached, which would create many difficulties with present drilling and logging techniques.

The Oberpfälz site is located at a suture-type boundary between two major basement units, the Saxothuringian and the Moldanubian that belong to the internal zone of the Hercynian orogen. This boundary can be traced throughout Europe. The crustal structure in the target area is characterized by intense Variscan thrust and nappe tectonics and offers a unique opportunity to study the fundamental processes of lateral crustal accretion. The geodynamic model presented for the evolution of the Oberpfälz region is petrologically and geophysically well substantiated, and the location is regarded as a key area for deciphering the structural and paleogeographic development of the European Variscides.

The upper crust of the Oberpfälz region is characterized by a high seismic reflectivity with a highly reflective crustal portion intercalated with low-velocity channels at a depth of between 10-12 km. A major goal of the research, therefore, is to unravel the nature of these seismic reflectors. A close mutual relationship is thus envisaged with the German Continental Reflection Program (DEKORP), which casts its seismic net over the Federal Republic and will most certainly profit from a super-deep borehole in the Oberpfälz. It is striking that these high-velocity zones have already been found repeatedly as intercalations in the Hercynian basement and that they are connected with zones of relatively high electrical conductivity.

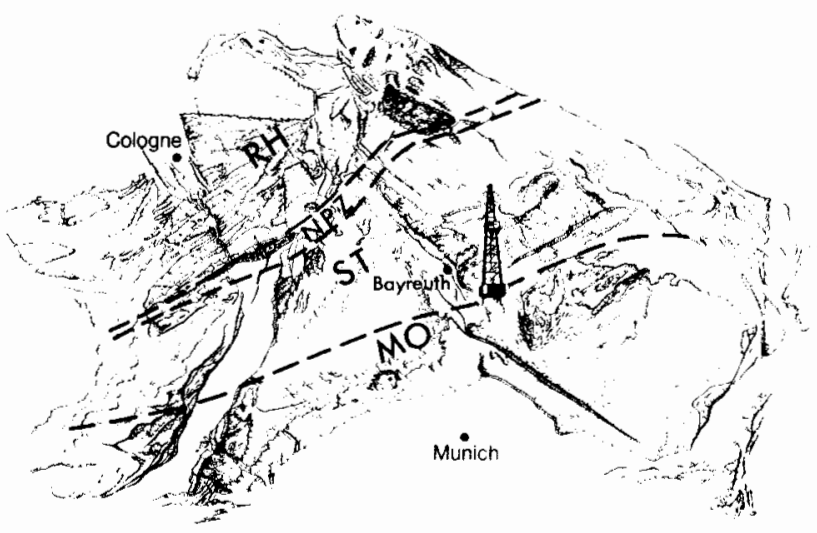

Figure 1: Regional setting of the Oberpfälz superdeep hole. Tectonic zones: RH - Rhenohercunian, ST - Saxothuringian, MO - Moldanubian, NPZ - Northern Phyllite. (From Springer Newsletter 1 1987) 


\section{News Reports}

A theme of outstanding importance is the investigation of the rock fluids. The Oberpfälz data document a polycyclical development of fluid systems and paleopermeabilities that can be linked with basinal brines and with tectonic, metamorphic, magmatic processes. It is, therefore, anticipated that the borehole will provide important contributions as to the role of crustal fluids with respect to thrusting, crustal deformation, secondary rock porosity and sealing, as well as to the formation of thrust-related mineralization.

The target area is marked by a wealth of mineralizations with varied parageneses. Besides massive sulphide deposits from the geosynclinal period, syn- to post-orogenic veins and replacement are widespread and are concentrated in culmination zones or connected to late to post-Variscan strike-slip-systems. In close proximity to the drill site lies the biggest quartz dike in Europe, the "Bayerische Pfahl," $250 \mathrm{~km}$ long and over $100 \mathrm{~m}$ wide. The target area, therefore, provides particularly favourable conditions for studying the relationship of many important types of deposits to variscan or post-Variscan events, as well as to metamorphic, magmatic or connate fluid systems.

The site area is also cross-cut by the western continuation of the Eger graben, a Tertiary rift structure associated with a gentle updoming of the mantle. This structure was accompanied by intense Tertiary volcanism and is now distinguished by numerous thermal springs, $\mathrm{CO}_{2}$-rich mineral waters, and radon springs that indicate circulation to great depths. The borehole will, therefore, provide not only information on the crustal development of the area 400-300 Ma ago and its Permian to Mesozoic crustal rejuvenation but also on more recent crustal processes. Investigations of the ${ }^{3} \mathrm{He} /{ }^{4} \mathrm{He}$ composition of thermal waters in the target area have yielded significant $3 \mathrm{He}$ enrichments that suggest the contribution of a mantle component.

Drilling of the main borehole, at a distance of about $200 \mathrm{~m}$ from the pilot hole, which is aiming for a target depth of $3000 \mathrm{~m}$, will be started in 1989 and by 1996 should have penetrated to a depth of 12,000-14,000 m. The total budget of the project is fixed at 450 million DM. The German scientific community anticipates that the many existing contacts in the field of continental drilling, particularly with the U.S.A, Canada, France, Switzerland, England, Sweden and other countries, will lead to a close international multi-disciplinary collaboration and the definition of cooperative scientific projects. $\square$

R. Emmermann Giessen, F.R.G., and H.-J. Behr

Hannover, F.R.G.

\section{IUGS Reviews Methods of Grain-Size Analysis}

In 1985, the IUGS Committee on Sedimentology set up a working group to develop a program of inter-instrument and inter-lab calibration of the many and diverse methods used by automated particle size analyzers. The first meeting was held at the Bedford Institute of Oceanography in early 1986 and provided a useful synopsis of the latest advances with respect to the theory, methods and calibration of size analyzers such as resistance counters, image analyzers, $\mathrm{X}$-Ray attenuance meters, or using laser beam techniques.

Two future objectives are the production of a textbook and the design of a permanent world-wide calibration network for modern and future methods of grain size analysis. The textbook will review the main theories and methods for automated analysis and will discuss the application of particle size results to oceanography, stratigraphy, coastal engineering, geochemistry, hydraulic research, and animalsediment and geotechnical studies. Those interested in contributing are invited to contact the working group convenor with a short description of the contents of the proposed chapter.

To meet the second objective, a set of standards that are relatively inexpensive, reproducible and independent of technique, have been developed. These are available at cost from Dr. Jiri Brezina (Granometry, D-6903 Neckargemünd3, Federal Republic of Germany). Analyses based on these standards will be presented at a second working group meeting to be held in Heidelberg, F.R.G., on October 7 and 8,1987 (for details contact Dr. Brezina).

J.P.M. Syvitski, AGC, Box 1006, Dartmouth, Nova Scotia B2Y 4A2

\section{Se106 Petrographic Thin Section Cutter-Grinder}

Easy to use, fast, accurate and designed to meet the demands of the modern geological laboratory, the NEW SG106 Petrographic Thin Section Cutter-Grinder - A revolutionary new concept in geological specimen sawing and grinding.

- Universal Vacuum Chuckface accommodates 6 off $28 \times 48 \mathrm{~mm}$ or 4 off $76 \times 26 \mathrm{~mm}$ or 2 off $76 \times 50 \mathrm{~mm}$ or 1 off $110 \times 76 \mathrm{~mm}$ slides

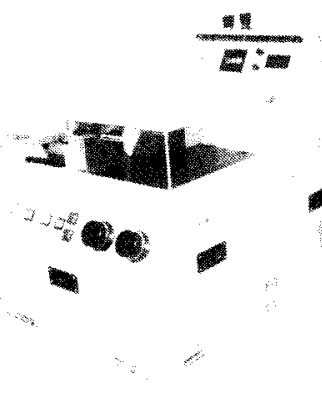

-Automatic Feed in Sawing Mode full automation at this part of the operation gives maximum productivity

- Sections Ground to 100 Microns or Less - depending upon the nature of the material, sections may be ground to less than 100 microns ready for final lapping by machine or hand

- Digital Readout - this option gives direct indication of specimen thickness

- Integral Vacuum and Coolant Services - housed in the machine for convenience

- Fully compatible with all other LOGITECH geological specimen preparation systems

Total technology from the world leaders in precision materials processing. FOR FURTHER INFORMATION PLEASE CONTACT:

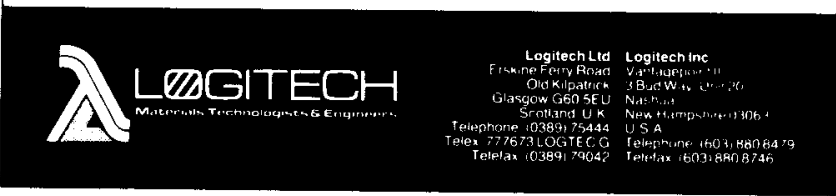




\section{ICSU Appoints Committee to Run IGBP}

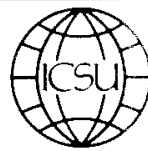

Detailed plans should soon be forthcoming for the International Geosphere-Biosphere Program (IGBP) approved recently by ICSU, the International Council of Scientific Unions. A Special Committee for IGBP has now been appointed to plan for and to oversee the program. J.J. MeCarthy (U.S.A.) is the convenor, and several of the 19-member group are geoscientists, including E.S. Diop (Senegal) and W.S. Fyfe (Canada).

IGBP aims to "describe and understand the interactive physical, chemical, and biological processes that regulate the total Earth system, the unique environment that provides for life, the changes that are occurring in that system, and the manner by which these changes are influenced by human actions." A four-year planning period is foreseen, with an operational phase expected to begin in the early 1990 s and continue at least until the year 2000. A high priority will be to initiate communications with appropriate national and international organizations such as the World Meteorological Organization. National committees will be formed to link with national research agencies, since many of the IGBP activities are likely to be funded and carried out at the national level. Sweden is providing the secretariat for the Special Committee under T. Rosswall (University of Linköping) as Executive Director.

The establishment of the IGBP mirrors the concerns of other scientific groups to develop a more holistic view of the interactions between the planet Earth and its life forms. The American Geophysical Union, for example, has set up its own "Earth as a System Committee," and the U.S. National Aeronautics and Space Administration, is also developing a program in "Earth Systems Science." The U.S. National Science Foundation has now allocated some $\$ 3.5$ million to its global geoseience program, which will be linked in part to the IGBP. The NSF program will concentrate on global tropospheric chemistry, global ocean climate, global ocean flux, global ecosystem dynamics, ocean ridge crest processes, and solid earth. $\square$

\section{SCOPE Highlights Phosphorus}

Phosphorus occupies a key place among the major nutrients because of its relative scarcity among the light elements and its essential role in energy transformations in all life forms. The widespread uses of fertilizer phosphate has greatly increased food production and contributed to the development of a relatively secure food supply for an expanding world population. On the other hand, $\mathrm{P}$ associated with eroded sediments from farm lands, as well as $P$ discharges from urban and industrial areas, are major causes of eutrophication of water bodies.

There is a growing need for guides to the use of $P$ so that maximum benefits can be obtained without producing undesirable environmental impacts. Extensive data are available in several parts of the world on mineral phosphate deposits, fertilizer production and usage, soils and plant composition in a variety of ecosystems, river transport, and lake sediments. However, information on the $\mathrm{P}$ cycle needs to be summarized and then integrated with knowledge of other nutrient elements and their interactions. Though $\mathrm{P}$ does not have a significant gaseous transfer to the atmosphere, it does have important indirect effects on the global environment through its impacts on carbon, nitrogen and sulphur transfers.

On a global scale there is no shortage of phosphate rock for use in industry and fertilizers, but high quality reserves are rapidly being depleted. This will result in the need to utilize lower grade ores with high contents of silica and sesquioxides. High production costs of soluble fertilizer products, together with indications of lower residual value, have stimulated the development of alternative approaches, including more direct application of reactive phosphate rock and partially acidulated products. Also, there is an urgent need to develop improved methods for recycling $P$ particularly from human and animal wastes.

Recent studies of $P$ transformations focus on microbial activity and the importance of both inorganic and organic forms, since the latter are both a significant source and a sink for biologically active $\mathrm{P}$ in ecosystems. Key processes of $\mathrm{P}$ interactions with carbon, nitrogen and sulphur have been identified and incorporated into computer models to guide interpretation of $\mathrm{P}$ data. These models need to be extended to a wider range of ecosystems to provide a mechanism for the key evaluation of shortand long-term impact of human manipulation of $P$ in the biosphere. A realistic understanding of the elemental cycles is not possible in isolation from other nutrients, and a holistic approach to global biogeochemistry is required.

To address these needs SCOPE, the ICSU Scientific Committee on Problems of the Environment, has now launched a major study aimed at a fuller understanding of the nature, sources and fluxes of $P$ and its global environmental effects. The project is aimed at assessing knowledge of the role of $\mathrm{P}$ in the biosphere, and at identifying mechanisms of supply of biologically active $P$ in terrestrial and aquatic ecosystems. Information will be provided to meet more effectively worldwide $P$ requirements for food and fibre production while minimizing its effects on environment. The project will also evaluate both the environmental effects of $P$ in relation to the biogeochemical cycles of carbon, nitrogen, sulphur and metals.

The SCOPE project will organize workshops in various parts of the world to synthesize data on the $P$ cycle in major ecosystems of each region. The project will also help to develop conceptual and simulation models of $P$ cycling in major ecosystems, and the information gathered will be integrated at a final international workshop to be held in India. This workshop is expected to provide a global perspective on the economic and environmental consequences of the use of $P$ resources.

The new phosphorus project joins others already under way by SCOPE on global carbon and nutrient cycling, and on the sulphur cycle in terrestrial and aquatic systems. $\square$

- from SCOPE Newsletter, November 1986 


\section{New Committee on Quantitative Stratigraphy}

\begin{abstract}
The IUGS Commission on Stratigraphy recently created a Committee on Quantitative Stratigraphy (CQS), in part as a follow-up to the highly productive IGCP Project 148 on quantitative methods of stratigraphic correlation. CQS promotes the acceptance and use of quantitative stratigraphy in paleontology, geology and geophysics.

Quantitative stratigraphy uses relatively simple to complex computer-based methods of mathematics and statistics to formulate stratigraphic models in order to provide a maximum of predictive potency with a minimum of data. The methods are applicable with unique, non-recurrent fossil ranges or fossil events in biostratigraphy, or with recurrent physical events in lithostratigraphy, well-log analysis, magnetostratigraphy, chemostratigraphy, seismostratigraphy, etc. Another important application involves the calculation of linear or non-linear time-scales and their development for use in refining the tectonic and burial histories of sedimentary basins.
\end{abstract}

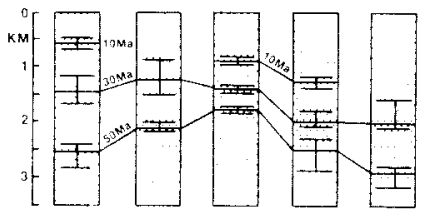

Correlation of stratigraphic events or units generally expresses the hypothesis that a mutual relation exists between them, as observed at different geographic locations. A major aspect of quantitative stratigraphy is the formulation of geologically meaningful confidence limits when correlating. The uncertainty in geological correlation expressed in stratigraphic or chronologic units of measurements provides insights into the validity of geological models and into the accuracy and precision of correlation techniques.

Many examples exist in the literature of the application of stochastic process theory to geological pattern recognition, yet only rarely is the intuitive definition of a lithostrati- graphic formation equivalent to a statistical population. Quantitative lithostratigraphy has, therefore, pursued several lines of investigation. It has taken the present intuitive formation and defined it using quantitative techniques such as time series, time trend, Markov, spectral, discriminate function, and fractal analyses. It has taken a series of observations and defined quantitative idiographic lithostratigraphic units, and it has defined quantitative exogenous lithostratigraphic units independent of the observations themselves. It has also developed simple deterministic process-response models that can be used to simulate the construction of a lithostratigraphic sequence from theoretical principles.

The concepts of quantitative or partial correlation require that the observations or process models to be correlated are strictly defined or have a specified precision if not accuracy. The aim should be in the direction of geologically acceptable definitions of "similarity" and "homogeneity" and a rigorous approach to lithostratigraphic unit definition. There are many techniques of quantitative correlation and sequence analysis available from other disciplines that can only find widespread application in geology after a consistent quantitative lithostratigraphic unit has been agreed upon.

To address these and other related problems, CQS will distribute a newsletter, promote exchange of stratigraphic data and computer programs, sponsor and organize short courses, meetings and symposia, publish a comprehensive bibliography, and sponsor comprehensive manuals and textbooks on various methods. The entrenchment of the new methods in standard stratigraphic philosophy and the acceptance of the new stratigraphy in university curricula are additional objectives. Finally, CQS will work toward the increased application of quantitative stratigraphy in economic geology, such as the exploration for oil and gas. Further information on CQS activities is available from the Chairman, F.M. Gradstein, Atlantic Geoscience Centre, Dartmouth, Nova Scotia, Canada B2Y 4A2. $\square$

\section{IGCP Applies Geochemistry to the Proterozoic}

IGCP Project 217, Proterozoic Geochemistry, is concerned with geochemical studies of early and middle Proterozoic terrains to improve the understanding of their origin and tectonic setting. The first of nine sub-projects is undertaking a comparison of Proterozoic supracrustal associations with similar ones of Archean and Quaternary age. This includes both geological and geochemical inputs in an attempt of evaluate the role of plate tectonics in the Proterozoic. The second sub-project is aimed at Proterozoic crustal evolution as recorded by detrital sediments of that age, in order to answer the question of whether there are important changes in crustal composition recorded in Proterozoic sediments as a function of age.

The reality of the apparent gap between 2.4 and $2.0 \mathrm{Ga}$ in the generation of continental crust is another topic being addressed, through the obtaining of more high quality radiometric dates, especially involving zircons: a better geochronology of Proterozoic terrains is likely to be one output. Trace elements and Nd isotopic studies of Proterozoic basalts are being carried out in order to monitor the composition of the upper mantle during the Proterozoic and the role of sediment recycling into the mantle. Other geochemical and isotopic studies are focussing on the rapakivi granite-anorthosite association so as to understand more completely the magma sources and tectonic regimes involved.

Isotopic studies involving $\mathrm{Nd}$ and $\mathrm{U}-\mathrm{Pb}$ will be expanded to continents other than North America to evaluate the rate at which new continental crust was added to existing continents during the Proterozoic. Another sub-project is looking at Proterozoic granulite facies terrains in order to see whether Proterozoic high-pressure granulites differ funda- 
mentally from their Archean counterparts. Finally, the origin and evolution of Proterozoic mineral deposits is being studied by comparisons with both older and younger deposits.

Project 217 held two conferences in 1986. The first, held in Nottingham, U.K., in April (see Episodes September 1986, p. 181), focussed on Proterozoic volcanic suites. Geochemical results presented indicate a striking similarity between early Proterozoic volcanic successions in North America and northern Europe, suggesting that a considerable amount of Proterozoic continental crust was accreted to Archean cratons in both areas by arc-collisional processes. On the other hand, geochemical data from Proterozoic terrains in Australia seem to reflect within-plate tectonic regimes.

In a second meeting held in Colorado, U.S.A., last July, participants from IGCP Projects 217 and 215 (Proterozoic Fold Belts) reviewed the role of plate tectonics during the Proterozoic. Although numerous lines of evidence, both geological and geochemical, suggest that plate tectonics existed throughout the Proterozoic, the delayed appearance of ophiolites, blue schists and mélanges until the late Proterozoic (approximately $1200 \mathrm{Na}$ ) seems to require changing tectonic regimes during the Proterozoic.
Some major questions that emerged during these conferences relate to crustal evolution during the Proterozoic. What do the differences and similarities between early and late Proterozoic volcanic assemblages reflect in terms of evolving tectonic styles? Why do ophiolites, blueschists and mélanges all appear at about the same time in the late Proterozoic? What unique event is responsible for the 1450 $\mathrm{Ma}$ anorogenic granites? And in comparison to the $2700 \mathrm{Mla}$ event at the end of the Archean, how widespread were Proterozoic crustal forming events, and how much reworking of Archean crust is involved in such events?

IGCP Project 217 is now planning a major meeting to be held this June in Lund, Sweden, to review the origin of Proterozoic granites. Future meetings are being planned for China (1988) and Zimbabwe (1989).

after report by K. C. Condie and W.R. Van Schmus

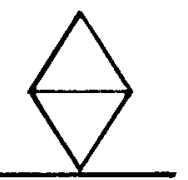

\section{The Commission on Systematics in Petrology}

A request in 1956 by Ernst Niggli to Albert Streckeisen and Theo Hugi to collaborate in revising the well-known "Tables of Petrography and Rock Determination" by Paul Niggli led to the beginning of the Commission's work. Although the original work eventually foundered, Prof. Streckeisen (Switzerland) continued with a review of the classificatory system and began an international discussion on the subject, publishing the results under the title "Classification and Nomenclature of Igneous Rocks: Final Report of an Enquiry" in 1967.

Subsequently at the suggestion of T.F.W. Barth (Norway), then IUGS President, a Subcommission on the Systematics of Igneous Rocks, with Streckeisen as Chairman and V. Tromsdorff as Secretary, was established under the Commission on petrology "to discuss the problems of systematics, classification and nomenclature of igneous rocks and to present definite proposals to IUGS."

Much of the Subcommission's work was done by correspondence. A preliminary meeting took place in Berne in April 1972 , and at the Montreal International Geological Congress the same year the IUGS Council replaced the Commission on Petrology with one on Systematics in Petrology, which had a Subcommission on Igneous Rocks, both with Prof. Streckeisen as Chairman. A subcommission on sedimentary rocks was not considered to be appropriate, and formation of another on metamorphic rocks was deferred in favour of the higher priority of the igneous work.

A great deal of work ensued, with the acceptance of the double triangle QAPF (Quartz, Alkali-Feldspar, Plagioclase, Feldspathoid) as the basis of a classification based on modal mineralogy. Sessions were held at the Montreal, Sydney, Paris and Moscow Geological Congresses (1972 to 1984), as well as at Grenoble, Padova, Cambridge, Granada, London and Freiburg, from 1975 to I986. Prof. Streckeisen's great contributions to this and other petrological fields were recognized in 1984 when the Deutsche Mineralogische Gesellschaft presented him with the Abraham Gottlob Werner Medal in Silver.

At Paris (1980), B. Zanettin (Italy) became the Commission Chairman, and he was succeeded in Moscow by P.A. Sabine (U.K.), with M.J. Le Bas (U.K.) as Chairman of the Subcommission on Igneous Rocks. New subcommissions were established on Systematics of Metamorphic Rocks ( $R$. Schmid, Switzerland, Chairman) and Data Bases in Petrology (F. Chayes, U.S.A., Chairman).

The principal result of the work on phanerocrystalline igneous rocks has been the widespread acceptance of the modal classification by means of the QAPF diagram, to which there have been minor changes such as the distinction of diorite and gabbro and the use of colour index. If their mineral content can be determined, volcanic rocks are also classified on this basis, if not, then chemical composition is considered. The focus of this work is on the TAS (Total Alkali-Silica) diagram, which has been elaborated especially by R.W. Le Maitre (Australia; see review by B. Zanettin, Episodes, December 1984). The classification of charnockitic rocks has been considered as well as that of melilitebearing rocks and carbonatites, and Dr. Le Maitre is preparing a glossary of igneous rock names.

The Subcommission on the Systematics of Metamorphic Rocks began its work in 1985 . It has 29 members from 21 countries, a Working Group comprising 100 colleagues from more than 20 countries, and 9 Study Groups. These deal with terms for very low-grade metamorphics, high pressure rocks, granulites, contact metamorphics, deformed rocks and structures, migmatites, carbonate and metasomatic rocks, and impactites. 


\section{News Reports}

The Study Groups prepare definitions of rock names and other terms, which are then discussed and eventually modified by the Subcommission members at their annual meeting. All these definitions and unresolved questions are then sent in questionnaire form to members of the Working Group whose responses are used to modify the proposed definitions. This procedure may be repeated until the best international agreement is achieved.

So far provisional decisions have been taken on definitions of terms including layer, foliation, blueschist, greenschist, eclogite, schist, and gneiss. A provisional definition of the latter is a "metamorphic rock with gneissose texture, in which feldspar is a major constituent and which usually contains quartz. The minimum amount of feldspar +/quartz is $30 \%$."

Those interested in cooperating with the Subcommission are invited to contact Dr. R. Sehmid, Chairman Subcommission on the Systematics of Metamorphic Rocks, Institute for Mineralogy and Petrology, ETH-Centre, 8092 Zürich, Switzerland.

-from Newsletter 1 (February 1987) of the Commission on Systematics in Petrology
NOW AVAILABLE:

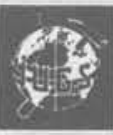

International

Union of

Geological Sciences

Publication No. 22

\section{THE ORDOVICIAN SYSTEM OF SOUTH AMERICA}

by F.G. Acenolaza and B. Baldis

1987

Correlation Charts and Explanatory Notes. 70 pages, 4 figures and 3 charts.

To receive your copy send $\$ 11.50$ (US) to: Episodes, Rm. 177, 601 Booth Street, Ottawa, Ontario Canada KIA OE8.

Copies may also be obtained from IUGS Secretariat, Geological Survey of Norway, PO Box 3006, N-7001 Trondheim, Norway, and from IUGS Liaison office, 103 rue de Lille, 75007 Paris, France.
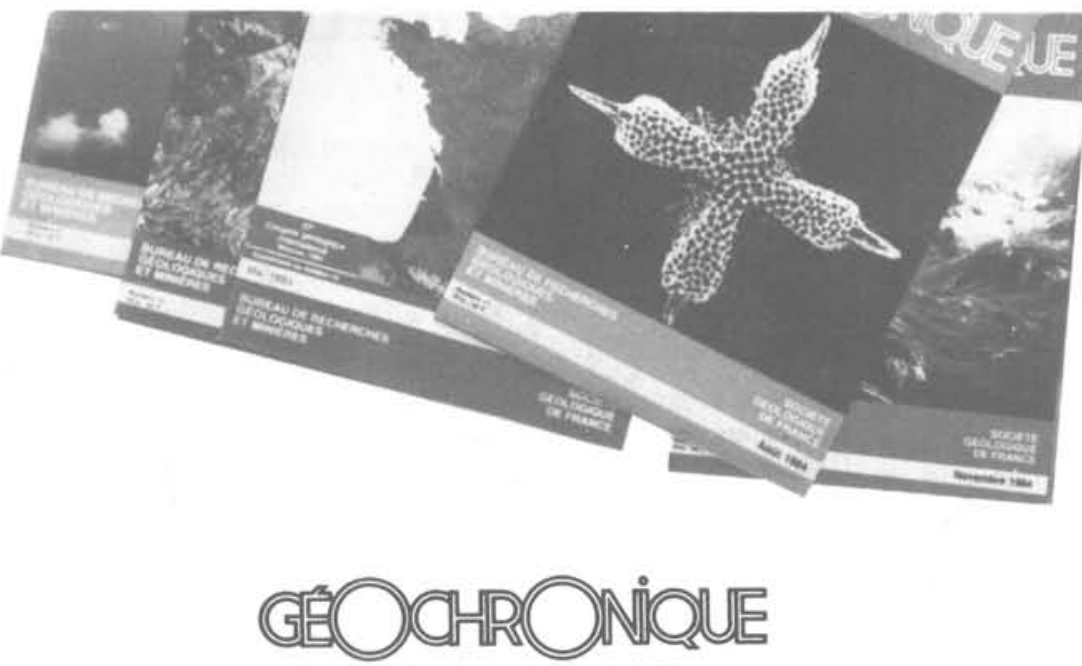

Le magazine des sciences de la Terre

The French language Earth Sciences magazine

La société géologique de France et le Bureau de recherches géologiques et minieres

Chaque trimestre Quarterly

Actualités géologiques

Geological news

Analyses d'ouvrages

Book reviews

Articles de synthese

Synoptic articles

Nouvelles des organismes

News of organizations

Échos des Associations

Society activities

Calendrier

Calendar coèdite par / published by

ABONNEMENTS SUBSCRIPTIONS
$35 \%$

France : $150 \mathrm{FF}$

Chèque à l'ordre de

Please, send you cheque

made out to Société Géologique de France

to the following address S.G.F...

77, rue Claude-Bernard

$10 \%$

$10 \%$

Tirage : 4300

Diffusee en France et dans les autres pays.

$10 \%$

$10 \%$
A free example will be sent on receipt of an addressed adhesive label.

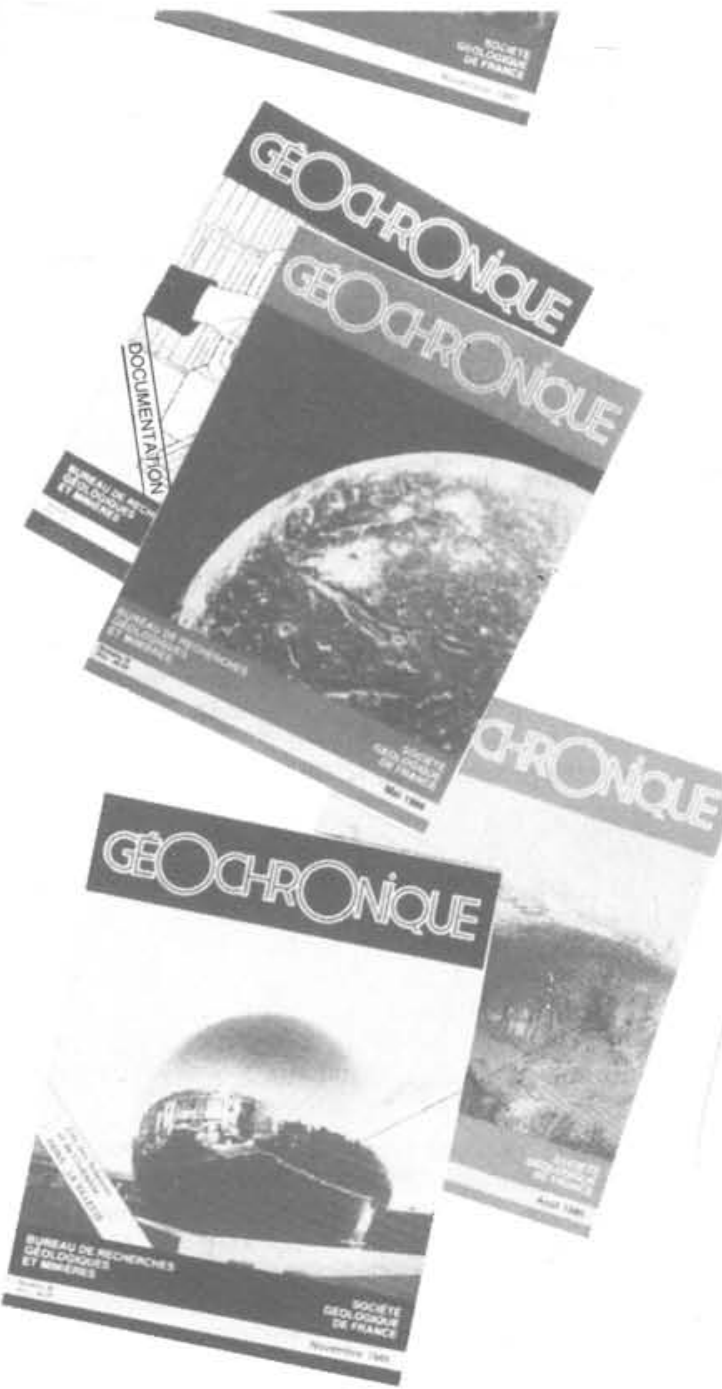

